\title{
A brief history of ball lightning observations by scientists and trained professionals
}

\author{
Alexander G. Keul ${ }^{1, ら}$ \\ ${ }^{1}$ Environmental Psychology, Salzburg University, Salzburg, Austria \\ «retired \\ Correspondence: Alexander G. Keul (alexander.keul@sbg.ac.at)
}

Received: 12 August 2020 - Revised: 17 December 2020 - Accepted: 15 January 2021 - Published: 1 March 2021

\begin{abstract}
With thousands of eyewitness reports, but few instrumental records and no consensus about a theory, ball lightning remains an unsolved problem in atmospheric physics. As chances to monitor this transient phenomenon are low, it seems promising to evaluate observation reports by scientists and trained professionals. The following work compiles 20 published case histories and adds 15 from the author's work and 6 from a Russian database. Forty-one cases from eight countries, 1868-2020, are presented in abstract form with a synthesis. The collection of cases does not claim to be complete. Six influential or notable ball lightning cases are added. It is concluded that well-documented cases from trained observers can promote fieldwork and stimulate and evaluate ball lightning theories. Scientists who have not reported their experience are invited to share it with the author.
\end{abstract}

\section{Historical outline}

"Guarda! Guarda!" (“See! See!") - calls from the Corsa dei Servi (central street, now Corso Vittorio Emanuele II) in the centre of Milan alarmed Lorenzo Butti, marine painter of the Empress of Austria. It was 18:00 LT (local time) in June 1841 , with a heavy thunderstorm outside. Butti looked out of the window where people were running in the rain under a reddish-yellow ball of fire. It travelled at window height of the second floor, rose higher, and then exploded at a church tower cross with a dull crash. The artist wrote his experience to physicist Arago. Arago's report was rediscovered by senior school official Walther Brand for his monograph "Der Kugelblitz" (1923, 2010), the only one in German to date.

Since Sur le tonnerre of French astronomer and physicist François Arago (1837), the term ball lightning (Kugelblitz, foudre globulaire) stands for a still unexplained group of metastable luminous phenomena in atmospheric electricity. Ball lightning appears seemingly random in time and space, lasts a few seconds, and disappears with traces or without. Because of its unpredictable occurrence, most of the collected material remains anecdotal.
Ball lightning monographies and reviews were accomplished, e.g. by Brand (1923, 2010), Singer (1971), Stakhanov (1979), Barry (1980), Smirnov (1993), Stenhoff (1999), Rakov and Uman (2003), Bychkov et al. (2010), Shmatov and Stephan (2019), and Boerner (2019). Ball lightning cases also have a psychological side, when it comes to eyewitness quality, (non-)reporting, and public and media event labelling. Here, everyday life theories or mindsets are more influential than science. However, research about lay theories (Furnham, 1988; Zedelius et al., 2017) has its focus on the social sciences and not physics, so the borderland of ball lightning, folklore, and public opinions has not been further explored.

In chapter 20 of their lightning handbook, Rakov and Uman (2003) summed up the status quo on ball lightning. The authors were puzzled by 2400 references in Stenhoff's book (1999), whereas their handbook on all lightning aspects comprises over 6000 . This was also remarked by Thottapillil (2005, p. 31) in his COST Action proposal P18 on the physics of lightning together with 30 European researchers and the consensus that "the reality of ball lightning is not in doubt." Rakov and Uman (2003, p. 656, p. 658) characterized ball lightning as "a phenomenon for which there exists numerous witness reports but little, if any, scientific docu- 
mentation such as photographs, videotapes, or other scientific recordings." They counted almost 5000 observation reports. "There may be more than one type of ball lightning and more than one mechanism by which ball lightning is generated", they continue, also "There have been many theories devised to explain ball lightning. None is completely satisfactory" and "many luminous phenomena created in the laboratory are claimed by their creators to be ball lightning". For the same reason, Turner called ball lightning research a "fragmented science" (2001).

\section{Methodology}

Chances to monitor the transient phenomenon directly are minimal: Tompkins et al. (1975) searched about 12000 photographic records of the US Prairie Meteorite Network that observed the night sky daily for over 10 years and found two probable ball lightning events. Other photographic or video records (e.g. 1935 Berlin; 1976 Transvaal, South Africa; 1978 Montafon, Austria; 1985 Lake Undugun, Russia; or 2003 Zwönitz, Germany) were also random products. Therefore, Singer (1971, chap. 5.B.2) and Stenhoff (1999, chap. 10.4) paid special attention to ball lightning reports coming from scientists or trained professionals. However, large databanks like Rayle's (1966; $N=112$ reports) and McNally's (1966; $N=513$ reports) from the US did not ask for observer's professions and degrees. Published ball lightning reports of scientists are scattered, and even more remain unpublished.

To explain the purpose and methodology of the following study, the author noticed that the present journal already carried two historical ball lightning case records (Vaquero, 2017; Dominguez-Castro, 2018). So it seemed to be the right place for an updated case review encompassing published (e.g. Singer, 1971; Stenhoff, 1999) as well as unpublished reports. An international attempt to collect scientists' reports was beyond the scope of this review, so it does not claim to be complete but can and will be expanded by forthcoming reports in the future. Finally, the review compiles 20 published case histories, adds 15 from the author's work and six from a Russian database. Forty-one cases from eight countries, 1868-2020, are presented in abstract form with a synopsis of case details. Also, six influential or notable ball lightning cases are mentioned. It is expected that accounts by trained observers in addition to systematically investigated material-evidence cases can develop this heterogenous interdisciplinary field.

The author, meteorologist and psychologist, collected, evaluated, and published European ball lightning cases for 45 years (Keul, 1980, 1981, 1992, 1993, 1994, 2004; Keul and Stummer, 2002; Kugelblitz, 2021). For most of this period of time, ball lightning case work was limited to single case investigations and statistical synopses, lacking an interdisciplinary perspective with forensic experts, materi- als science, lightning protection experts, etc. The upswing of modern lightning location networks (like BLIDS, German lightning information service, or ALDIS, Austrian lightning detection and information system) opened up new options, so recently, a first correlation of 34 central European ball lightning events, 1994-2016, with lightning location data was done together with ALDIS (Keul and Diendorfer, 2018). Nineteen detected strokes, correlated in time with ball lightning, were positive (4-370 kA peak current) and 15 were negative ( -3 to $-37 \mathrm{kA}$ ). Twenty-eight were cloudground strokes and 6 were cloud-cloud strokes; 28 occurred in the summer months and 6 in winter. Seventeen events had close-distance lightning strokes - ball lightning under $1 \mathrm{~km}$ (mean $0.42 \mathrm{~km}$ ), and 17 were distant events $(1-10 \mathrm{~km}$, mean $5.7 \mathrm{~km}$ ). The unexpectedly high number of positive strokes and the equal frequency of close and distant events were discussed at the 34th International Conference on Lightning Protection.

\section{Scientists as ball lightning observers}

\subsection{Natural scientists, technical, and medical professionals}

We start our series of cases with a chronology of eyewitness reports by natural scientists, and technical and medical experts. Several alleged observations (e.g. of Niels Bohr and Victor Weisskopf), often quoted in science or popular journals, were incorrect or lacked data: Tuck (1971) only wrote that he heard from Weisskopf that Bohr had once seen ball lightning. Martin Ryle was quoted without details by Davies (1987). Pyotr Leonidovich Kapitsa developed a ball lightning theory but reported no alleged sighting.

Geologist and mineralogist Wilhelm von Haidinger, member of the Imperial Academy of Sciences at Vienna, observed ball lightning from his home at Vienna's 3rd district Landstrasse on 20 October 1868, in a heavy thunderstorm between 17:15 and 17:30 LT: "The electric fireball was one of the very first discharges of the thunderstorm ... It stood maybe 2-3 s in front of the right pane of the window ... It is indeed simple to describe the ball, of a vivid yellow light, especially on the right ... while on the left ... clearly red, with longer rays than the ball, firing from it to the right and towards the earth, of red, yellow colour, up to the most dazzling white. Also, left there were shorter rays inclined obliquely towards the earth.... Several discharges followed and after [them] hail and rain." Haidinger (see his sketch in Fig. 1) determined the object's angular diameter as $0.83^{\circ}$. After his observation at Ungargasse 3, 3rd district, to the southwest, Haidinger heard about other occurrences in Vienna. Four of them sound like ordinary lightning but two described ball lightning: P. Joseph Dobner, Haidinger's friend, took shelter from the thunderstorm in a friend's home at Magdalenenstr. 32, 6th district. He saw a glaring blue sphere outside the window to the southeast. No more details are given. Another 


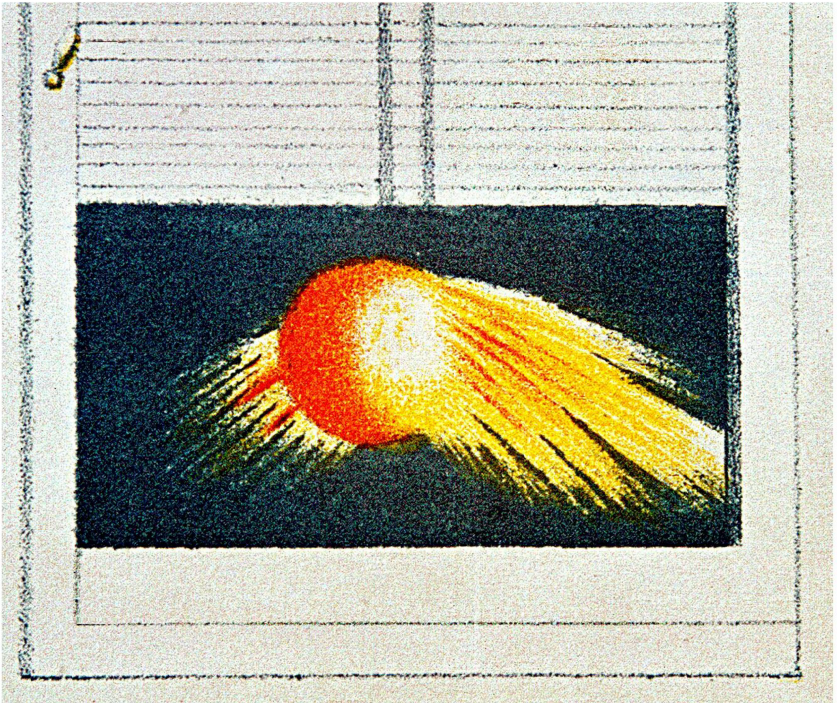

Figure 1. Colour drawing of Haidinger's object as seen in the window frame; supplement to his 1868 case report to the Imperial Academy of Sciences, Vienna. Reproduction of image detail: Axel Wittmann.

observation came from Mrs Wassmann from the backhouse of Westbahnstr. 28, 7th district, who saw a full-moon-sized ball to the southwest, coloured red-yellow, that emitted rays like a firewheel three times in $1 \mathrm{~min}$ lifetime. It was motionless like the two others. So we get a 1868 multiple object event with sightings from three inner Vienna districts, Landstrasse, Mariahilf, and Neubau, in a triangle $3.4-1.3-3 \mathrm{~km}$ apart, with two similar objects (colour, size, rays) and a different one. Haidinger described the "electric meteors" in a report to his academy (Haidinger, 1868; Brand, 1923, 2010, p. 34).

Othniel Charles Marsh, professor of palaeontology at Yale University, USA, and president of the US National Academy of Sciences, was on board a large yacht in the harbour of Southampton, Hampshire, UK, on 23 July 1878. He later wrote a report to Nature (1895). During a violent thunderstorm, his attention was drawn to a light coming down from the foremast: "This light was a ball of fire, a delicate rose pink in colour, pear-shaped in form, with the large end below, and appeared to be 4 or $5 \mathrm{in} .(10-13 \mathrm{~cm})$ in diameter and 6 to 8 in. $(15-20 \mathrm{~cm})$ in length." "The object struck the deck with an explosion that knocked down the mate, [and it] apparently got down a windsail ventilator into the galley where it flung a large tin pan from the hands of a cook and upset things but caused no major damage. Witnesses of the crew were shocked, but all remained uninjured." "A strong ozone-like odour was observed immediately after the explosion" (Marsh, 1895, p. 152).

Ernesto Cabellero Bellido, professor of physics and director of the power station at Pontevedra, Galicia, Spain, gave the following report: on 2 January 1890, at 09:15 LT, a fire- ball the size of an orange appeared in the power station, oscillated between the switchboard and the dynamo and fragmented at the floor with a noise like a cannon shot. The net was interrupted for a few seconds, and copper cables on the switchboard were fused; otherwise, there was no damage (Anonymous, 1890). This incident was widely publicized in 12 scientific journals (Stenhoff, 1999).

Stanley Singer (1971, pp. 29-33) lists several accounts of natural scientists in his book, starting with Belgian astronomer M. E. Bijl, who saw in 1905 a red glowing ball with halo near his observatory. Abbott Lawrence Rotch, US meteorologist, founder of the Blue Hill Observatory south of Boston, and pioneer of kite soundings, saw and described ball lightning after lightning hit the Eiffel Tower in Paris in 1903. The bright ball, size $1 \mathrm{~m}$, fell from the top to third platform, about $100 \mathrm{~m}$ in $2 \mathrm{~s}$, where it disappeared. The tower guard knew other similar events (Singer, 1971). The time of $2 \mathrm{~s}$ for $100 \mathrm{~m}$ was faster than the free fall which would have taken about $5 \mathrm{~s}$.

Walther Gerlach, physics professor at the University of Tübingen, wrote a report to Naturwissenschaften on 20 May 1927: "On 9 May 1927, 08:00 [LT] I observed ball lightning [at Tübingen] ... I happened to stand at the window ... In the northeast, linear lightning went down with strong ramifications. From it (apparently out of a sharp kink) came a bright luminous yellowish-white ball in a considerable height and flew to the southwest. The time between lightning and the ball's flyover of our institute was roughly $1 \mathrm{~s}$. It could be observed for another second in the same appearance on its straight trajectory, soundless. Two seconds later, a not very strong thunder started, and $1.5 \mathrm{~s}$ after its start, there was an extraordinarily violent detonation, like an explosion bang." Gerlach did his calculations: with a speed of sound of $330 \mathrm{~m} \mathrm{~s}^{-1}$ and observed times of the lightning's thunder and the explosion, he got a ball lightning trajectory of $1300+1150=2450 \mathrm{~m}$. In $2 \mathrm{~s}$ flight time, "ball lightning had a mean speed of about $1200 \mathrm{~m} \mathrm{~s}^{-1}$ ". "I learnt at noon that the ball hit a small, barn-like house on the edge of Tübingen which is $1100 \mathrm{~m}$ distant ... the top of an electrical mast was smashed nearby." Gerlach also mentioned bluish "spraying" of electrical wires and blown fuses in "a whole row of houses" (Gerlach, 1927). His speed calculation of $1225 \mathrm{~m} \mathrm{~s}^{-1}$ is quite amazing, because it means the object travelled at a speed of Mach 3.6 "soundless", without an acoustic effect (sonic boom). This is one of the rare occasions where ball lightning met a gifted experimental physicist. Gerlach is renowned for his 1922 experiment about spin quantization in a magnetic field.

James Durward, a British military meteorologist, 19361940 director of the Iraq Meteorological Service (Anonymous, 1956), encountered ball lightning on his flight to Iraq in summer 1938. When the BOAC flying boat was in the Toulouse area in nimbostratus, a ball came in through the plane's cockpit window; burnt eyebrows, some hair, safety belt, and a dispatch case of the pilot; and then passed the dis- 
patcher and went into the rear cabin, where Durward saw it explode. James Durward also reported a ball lightning observation near Loch Tummel, Perthshire, Scotland, in summer 1934, where his 12-year-old son was opening an iron gate for the car passage in heavy rain and a moderate thunderstorm. Durward saw a 12 in. [30.5 cm] ball approaching from a pine forest to the left. It struck an iron gatepost and temporarily paralysed the arm of his son, who had the hand on the latch, yelled, and could not lower his arm for several hours (Gold, 1952; Singer, 1971; Stenhoff, 1999).

The German graduate physicist Hans Dolezalek, working on atmospheric electricity after 1961 for the US Navy, reported his own observation at Tübingen, BadenWürttemberg, Germany (Dolezalek, 1951). On 8 June 1951, about 17:00 LT, a thunderstorm started. Minutes before 18:00 LT, Dolezalek saw ball lightning like a car headlight $30 \mathrm{~m}$ away, moving downwards aslant with about 50$100 \mathrm{~m} \mathrm{~s}^{-1}$, disappear behind trees. A violent bang was heard, like an explosion or a grenade launcher, followed by a rising blue smoke cloud. The object's impact with $10 \mathrm{~m}$ bright rays spreading upwards was seen by another observer in a meadow. Later, a $50 \mathrm{~cm}$ burned spot was found. Two isolators of a $5 \mathrm{kV}$ power line pylon $5 \mathrm{~m}$ from the impact point were damaged. Neckar power station Hirschau (connected to the $5 \mathrm{kV}$ line) registered an interruption at 17:54 LT.

Coroner Leopold Breitenecker, later a forensic medicine professor at Vienna University, encountered ball lightning at Ternitz, Lower Austria, in the summer of 1955, 16-17:00 LT. He carried out an autopsy with a colleague in an old mortuary during a heavy thunderstorm, when lightning struck and threw the electricity meter out of the wall. From the hole in the wall, a fist-sized, sharply outlined ball descended to the floor, radiating a bluish white light like a welding arc. It moved $5 \mathrm{~cm}$ above the floor to the open door but disappeared into the stone wall beneath the door frame. The witness threw down his instruments and leapt to the door just in time to see the ball (apparently after passing through a crack in the wall) move across the vestibule and out of the mortuary's front door. It bounced down the steps like a toy ball and disappeared into a grave mound after travelling $8-10 \mathrm{~m}$ in about $5 \mathrm{~s}$ (Keul, 1980, 1981). Breitenecker saw ball lightning a second time from Mühlbach/Attersee, Upper Austria, in the summer of 1975, late afternoon, looking towards Mt Schafberg in a thunderstorm with many lightning flashes. Suddenly, a distant fireball travelled horizontally along a mountain wall, then burst sparking, like a spray candle.

Roger Clifton Jennison, a radio astronomer at Jodrell Bank Observatory, UK, from 1965 professor for physical electronics at the University of Kent, Canterbury, travelled with an Eastern Airlines night flight from New York to Washington on March 19 1963. According to his report to Nature (1969), shortly after midnight, a lightning strike happened during a thunderstorm and, seen from his cabin front seat, "a glowing sphere a little more than $20 \mathrm{~cm}$ in diameter emerged from the pilot's cabin and passed down the aisle of the aircraft approx- imately $50 \mathrm{~cm}$ from me, maintaining the same height." The witness estimated the object's velocity at around $1.5 \mathrm{~m} \mathrm{~s}^{-1}$, the optical output of the solid blue-white ball as 5 to $10 \mathrm{~W}$, its diameter as $22 \mathrm{~cm}$, and the height above floor as $75 \mathrm{~cm}$. The Jennison report reached a high international media impact.

Atmospheric chemist Dmitriev (Dmitriev, 1967) was on an expedition at the Onega river, Arkhangelsk Oblast, Russia, on 23 August 1965, near a string of wooden rafts. Shortly before 20:00 LT, in thunder and fine rain, there was a nearby lightning strike. Dmitriev saw ball lightning $1-1.5 \mathrm{~m}$ above the rafts, moving along the raft string towards his tent. Luminosity was high; it had a bluish tint, a core of $6-8 \mathrm{~cm}$, and an outside shell of $11-16 \mathrm{~cm}$. Crackling and sparking was heard. The object passed overhead, stopped a few seconds, then flew to a nearby forest edge, colliding with trees and dissolving. Dmitriev had evacuated gas sample bulbs at hand and took four air samples 55-70 s after the ball's passage from its trail of bluish smoke. The samples contained a maximum of $1.3 \mathrm{mg} \mathrm{m}^{-3}$ ozone $\left(\mathrm{O}_{3}\right)$ and $1.6 \mathrm{mg} \mathrm{m}^{-3}$ nitrogen dioxide $\left(\mathrm{NO}_{2}\right)$, which was 50-100 times higher than in normal air (Singer, 1971; Barry, 1980; Smirnov, 1993). Ball lightning over a river was also seen by geologist Thomas Leslie Tanton and members of his team in rural Ontario, Canada, 1918 (Singer, 1971).

Alexander E. Mickelson, doctor of technical sciences, was in a cottage house $17 \mathrm{~km}$ from Riga, Latvia, on 7 June 1967 , with distant lightning flashes outside but no rain. He listened to music on his shortwave battery radio Spidola that was not connected to the mains. At about 23:20 LT, lying on his back, he wanted to switch off this radio with his left hand when a white ball with a blue tint, diameter about $20 \mathrm{~cm}$, came out of the Spidola metal front panel and stopped above his hand, $8-10 \mathrm{~cm}$ from the switch. "The ball was not bright ... it stood in one place. I froze in surprise. The hand remained in the same position, 3-4 s passed, the ball exploded or rather snapped shut and disappeared ... with a short dry sharp and very loud sound. The sound woke up my wife and two children ... in the same room. ... Rising to a sitting position, I realized that I was alive." However, his left hand up to the elbow was paralysed and numb. The right hand was unharmed. "After intense rubbing of the hand for an hour, the numbness ceased, ... but it was difficult to move it." A black spot of 3-4 cm formed on the witness' back; also, 10-12 red circles of 1-2 mm on the skin of the left arm from hand to elbow were reported. His right hand gave his wife an electric shock when touched. The $15 \mathrm{~m}^{2}$ wooden house had shielded electrical wires with two $6 \mathrm{~A}$ and two $15 \mathrm{~A}$ fuses. It was found that both $6 \mathrm{~A}$ fuses had blown; network and TV set (switched off and plugged out) were intact. Neighbours told the family of a very loud thunderclap at about 23:30 LT which was not heard by the witness. The spots on Mickelson's arm did not hurt, but the spot on the back gave a slight pain until $1 \mathrm{~h}$ later. The next day he was painless, and the back mark disappeared 
after 3-4 d (report before 1987; Vladimir Lvovich Bychkov, personal communication, 2020).

Eric Dunford, space scientist at the Rutherford Appleton Laboratory, between Harwell and Chilton, Oxfordshire, UK, saw ball lightning with his wife and another person on 18 April 1968, at about 19:15-19:30 LT during a thunderstorm with heavy rain. After a (ground) flash less than a mile from the house, "an intense spherical ball of light appeared, angular diameter ... about half the sun's ... brightness was sufficient to light up the surrounding fields. ... there was a tail of light (or smoke) attached to the ball." It "did not move very much", lasted about $5 \mathrm{~s}$, then disappeared slowly. The true diameter could have been 4-8 m (Stenhoff, 1999, pp. 168-169).

In August 1968, graduate engineer Alfred Geiswinkler stayed with his wife at a Maria Wörth villa, Carinthia, Austria, near Wörthersee. Around 15:00 LT, during a heavy thunderstorm, a bright shining ball of about $20 \mathrm{~cm}$ with a discharge corona crossed the room $1.5 \mathrm{~m}$ away. Its outline looked sharp and the colour was white-blue with a reddish touch. Hissing like a Xmas sparkler, it went out on the balcony, along a balcony pillar to the ground, and a further $300 \mathrm{~m}$ out onto the lake, disappearing with thunder and lightning. It followed a linear track above the floor and rotated, singed the wooden balcony pillar, and caused a sulfur-like smell in the room. Both witnesses suffered a shock. Alfred Geiswinkler, who made his report to the author 1979 (see his sketch as Fig. 2), was then technical director of BEWAG, the power company of Burgenland federal province (Keul, 1980, 1981).

On 19 July 1978, aeronautical meteorologist WolfDietrich Wagner watched a nighttime thunderstorm from the window of his summer resort in Drobollach, Carinthia, Austria. A few minutes before a shower, at 00:58 LT, lightning struck Lake Faaker $400 \mathrm{~m}$ away. At the impact point, the witness saw "an ellipsoid, a luminous form like a discus ... that moved slowly northeastwards and exploded after a short lifetime (2-3 s)." The fireball illuminated "about half of the lake's surface with pure sodium yellow light". It had a $1 \mathrm{~m}$ compact, dazzling core in a blurred foggy shape of 2-3 m. The cylinder moved slowly over the water surface without rising according to Wagner's 1979 report to the author (Keul, 1980, 1981).

Retired general practitioner Elfriede Wustinger left her house in Vienna-Gersthof, Austria, on 26 March 1979, at 15:00 LT. Amidst approaching showers in light rain she saw a fuzzy red ball, somewhat flickering, which moved from north to south for several seconds before it was hidden by houses. The object was soundless, had brighter and darker spots, and moved below the clouds. The author received her report by telephone on the same day (Keul, 1980).

Sir Alfred Brian Pippard, professor of physics, F.R.S., reported ball lightning at the Cavendish Laboratory, Cambridge University, Cambridgeshire, UK, on 3 August 1982, after 16:00 LT in a violent thunderstorm. Among several close cloud-ground flashes, one near the Bragg building caused ball lightning which was noticed by several staff members from the Mott building as a bright object, "luminous haze", and as stationary blue-white light. Three more observers saw a ball moving over the ground, bright bluewhite light, visible for 4-5 s. An assistant at the ground floor photocopier was about to close the window when a bright, spinning, pyrotechnic-like object flew in, rebound from the photocopier, and flew out again (Stenhoff, 1999).

Willi Millitzer, a graduate engineer for traffic accident analysis, reported his 1984/1985 ball lightning observation to the author in 2006. Travelling from Frankfort to Berlin in a GDR Ilyushin plane in a summer or autumn evening flight, it crossed a heavy thunderstorm over the German Democratic Republic territory. Looking out onto the right wing, Millitzer and a colleague saw a red fireball, $30-40 \mathrm{~cm}$, travel along the wing centre, right to left, for 3-4s and disappear upwards without a direct lightning strike.

Rakov and Uman (2003, pp. 659-660) quote the report of a professional engineer. In October 1993, early evening, he was sitting at his upper floor desk in a wood frame house near Seattle, Washington, USA. It was raining heavily, and the window opposite was shut; $2-3$ min after a thunderclap, "I was astonished to observe a bright white ball of light, $1 \mathrm{ft}$ [30.5 $\mathrm{cm}]$ away from my face and about $6 \mathrm{in} .[15 \mathrm{~cm}]$ above my Mac." It came from nowhere, lasted for $3 \mathrm{~s}$, and had a 912 in. [23-30 cm] diameter. "The ball 'burst' and disappeared with a moderately loud, electrical sounding 'click', and there was an instantaneous, loud thunderclap that sounded as if it was right above my house." No trace, no smoke, or no odour was left; there was no damage to the house, and the computer worked when switched on.

Runar N. Kuzmin, physics professor, at the end of July 1997, 14:30 LT, was at Leninskiy Prospekt bridge near the Yuri Gagarin monument, central Moscow. Before a storm, "unexpectedly, ball lightning smoothly passed by the faces of the observers at a distance of $15 \mathrm{~cm}$. Two observers saw a spherical blue jellyfish with a slight yellowish tint, $10-12 \mathrm{~cm}$ in diameter. It looked as if alive. A film moved over the surface, colour shades changed, as on a soap bubble or a thin film of gasoline on water ... No heat was felt; the monument's pedestal was barely visible through the film. The object silently floated over the railing of the bridge, descended and went out of sight. Ozone odour was noticed." "Then, a trolleybus drove through a pothole on the bridge, its trolley pole shortly detached from the $500 \mathrm{~V}$ wire, and the discharge generated another object, a white ball, which separated ... grew a little, ... smoothly passed over the railing of the bridge, and, descending ..., exploded noiseless, about $1.5-2 \mathrm{~m}$ from the earth, scattering a sheaf of sparks. Its size was more than a meter. Before exploding, it slightly decreased in size, turned red, and a darker core appeared inside." In July 2000, V. Shmonina observed the formation of ball lightning at the same place near a tram during a thun- 


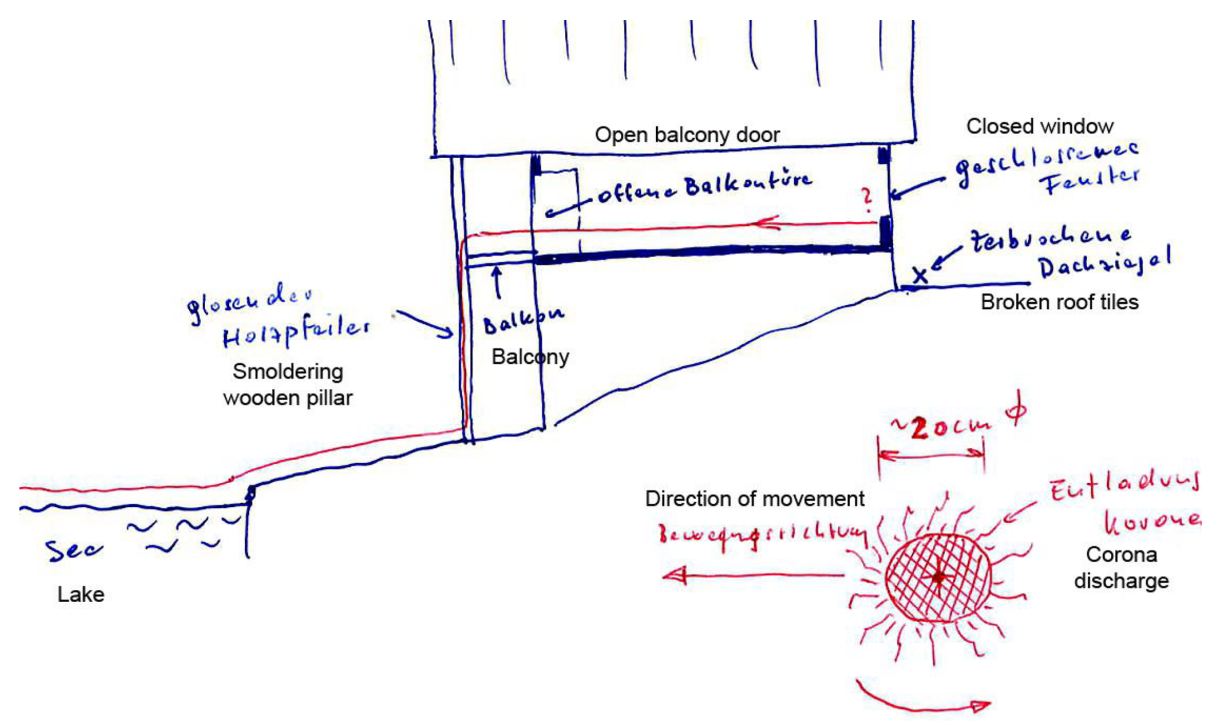

Figure 2. Sketch 1997 by Alfred Geiswinkler about his 1968 observation. Reproduction and English inserts: author.

derstorm (report 1997; Vladimir Lvovich Bychkov, personal communication, 2020).

Physics professor Vladimir Lvovich Bychkov, then working at Thousand Oaks, California, USA, returned home on 25 October 2002, at 21:30 LT. In his 2005 note he remembered smog, and it was dark and windy. "I walked downhill along a dimly lit street. Suddenly, 20-30 m above a palm tree $50 \mathrm{~m}$ from me, near my house, a bright object lit up noiselessly. It was white, had about $500-1000 \mathrm{~W}$ brightness, approximate size $30-40 \mathrm{~cm}$, was falling down for about $2-3 \mathrm{~s}$ at $1 \mathrm{~m} \mathrm{~s}^{-1}$, and then silently went out. There were no people nearby, it was no firecracker, and did not fall from a plane" (Vladimir Lvovich Bychkov, personal communication, 2020). Camarillo airport, $27 \mathrm{~km}$ west, reported $88 \%$ relative humidity and $4.6 \mathrm{mph}\left(7.4 \mathrm{~km} \mathrm{~h}^{-1}\right)$ ENE wind at 20:55 LT. It was cloudy, with local rain showers possible. As high object brightness was reported, we note that adaptation luminance is lowered by a night setting (Schreuder, 1998), so a ground glass $500 \mathrm{~W}$ incandescent light bulb (now phased out) will glare with $5 \times 10^{5} \mathrm{~cd} \mathrm{~m}^{-2}$.

\subsection{Childhood reports of later natural scientists}

A special category of reports is ball lightning encountered by children who, in their later life, followed a scientific career and then described in detail what they saw. It can be argued that all children have similar observation capabilities. However, scientific training and profession might improve the quality of their recalled eyewitness testimony. Therefore, four such accounts are included in this compilation:

Valentin A. Belokon, 7 years, later theoretical physicist and mathematician, was in July/August 1941, 14-16:00 LT at Zolotonosha, southeast of Kiev, Ukrainian Republic USSR (now Ukraine), in an old-style Ukrainian hut with a gabled hay-covered roof. At the end of a thunderstorm, there was a clash and a thunderclap. A sheaf of sparks came from a lamp halfway under the hut's ceiling. "Everyone was numb. I jumped up and ran out to see if the hut had caught fire. ... The roof was off. Returning, I began to open the door ... turned around and saw a melon-shaped body slightly flattened, $20-50 \mathrm{~cm}$. It went with an air flow ahead of me, entered the house, passed the rooms." "When the object passed me, it was at eye level ... It was translucent, like a honeycomb structure or cells (maybe filled with vortices); ripples were visible inside, colour like an opaque hospital lamp. Observation time was $15-20 \mathrm{~s}$, shortest distance $\sim 30-50 \mathrm{~cm}$, distance covered about $20 \mathrm{~m}$. Also, members of our family, sitting in the room under the lamp, observed the ball lightning", which flew out of a window (report 2005; Vladimir Lvovich Bychkov, personal communication, 2020).

Idea M. Naboko, 17 years, later physicist and mathematician, was on 15 July 1948, 14-16:00 LT at Tushino, northwest Moscow, Russia, with four people. On a hot day, a thunderstorm set in with short rain. After the rain, she walked out a shop door, "I saw this phenomenon ... at a height of 6-7 m. It flew smoothly, straight to the metal girder of a high-voltage transmission line, ... touched it and discharged with an explosive ... bright flash. It left on the surface of the girder a stain of oxidized metal and drops as from welding. We examined these tracks in the evening." The ball was $15-20 \mathrm{~cm}$ in size, pulsating, iridescent; colour was reddish, purple-blue, and dim. It glowed like a 10-20 W light bulb. Shape changed from spherical to ellipsoidal. The border was unsharp, shimmery; observation time was about $60 \mathrm{~s}$. Ball lightning travelled $10 \mathrm{~m}$ at $20 \mathrm{~m}$ distance from the observer (report 1991; Vladimir Lvovich Bychkov, personal communication, 2020).

Anatoly Il'ich Nikitin, physics professor at the Russian Academy of Sciences, 2005, recalled an observation when he 
was 9 years old. In mid-August 1948, about 20:00 LT, in Belaya Glina, northwest of Krasnodar, south Russia, "I walked along a village street ... on a hot summer day without rain." Left were telephone poles 3-4 m high with four telephone wires, and to the right was the sunset in clouds. "Suddenly I noticed a red ball about $15 \mathrm{~cm}$ in diameter, about $30-40 \mathrm{~cm}$ above the wires. ... sharp border, it shone against the blue sky, ... not dazzling, ... perfectly spherical ... slowly (about $1 \mathrm{~m} \mathrm{~s}^{-1}$ ) moving over the wires. ... along the middle line.... The ball was in my field of vision for about a minute, after which it disappeared behind the foliage of trees." The event was soundless (Vladimir Lvovich Bychkov, personal communication, 2020).

Axel D. Wittmann, astrophysicist of the Göttingen university observatory, saw ball lightning as a child on 8 July 1951, 17:30 LT, at Neustadt bei Coburg, Bavaria, Germany. He reported it to Nature (Wittmann, 1971) and in more detail at the Salzburg Vizotum congress Wittmann (1993). His uncle, industrialist Christian Wilhelm Foerster, wrote a memory $\log$ the following day listing all five observers. In a thunderstorm with heavy rain, Wittmann looked out into a street with other people. "Suddenly, ... I saw a spherical plasma ball coloured bright yellow white ... diameter of 50 to $100 \mathrm{~cm}$. It moved vertically downwards" into a treetop where it "disintegrated into 8 to 12 smaller spheres ... the same colour as the large one ... and each ... a diameter to 12 to $15 \mathrm{~cm}$. They fell to the ground.... On reaching the ground (an asphalt roadway...) the spheres instantly disappeared" (see the synopsis of Fig. 3 prepared by the witness). No lightning was seen, no sound heard. The event lasted about $6 \mathrm{~s}$. "Three to $5 \mathrm{~min}$ afterwards, the same phenomenon occurred again in precisely the same way as before" When the rain stopped, the witness went out to the street and found "circular patches of melted asphalt on the wet ... roadway which showed ... interference colours." Their diameters were the same as of the smaller spheres. Taking into account water layer and the melting point of B-80 bitumen, Wittmann "calculated the energy density of the plasma spheres to be at least $1.9 \times 10^{7} \mathrm{~J} \mathrm{~m}^{-3}$ " (Wittmann, 1971, 625).

Several other childhood reports of later scientists were discussed by Stenhoff (1999): J. C. Bass 1938 at Murree Hills, India; Jack Katzenstein at Shreveport, USA; Harrison Matthews 1916/1917 at Clifton/Bristol, UK; F. J. Hiorns $1939 / 1940$ at Kings Thorpe Grove, UK; James L. Guthrie 1944; and A. T. Donaldson 1963/1964 at Reading, UK. Also, Leonard B. Loeb 1898/1899 at Springfield, USA (Humphreys, 1936). Domokos Tar saw ball lightning as physics student, 1954, at the Budapest Margaret Island (Tar, 2006). In Bychkov's Russian case files (2020), there are also the short reports of Alexander N. Kabanov 1954, Chimkent, south Kazakh Republic, and Vladimir A. Ivanov 1982, Moscow region.

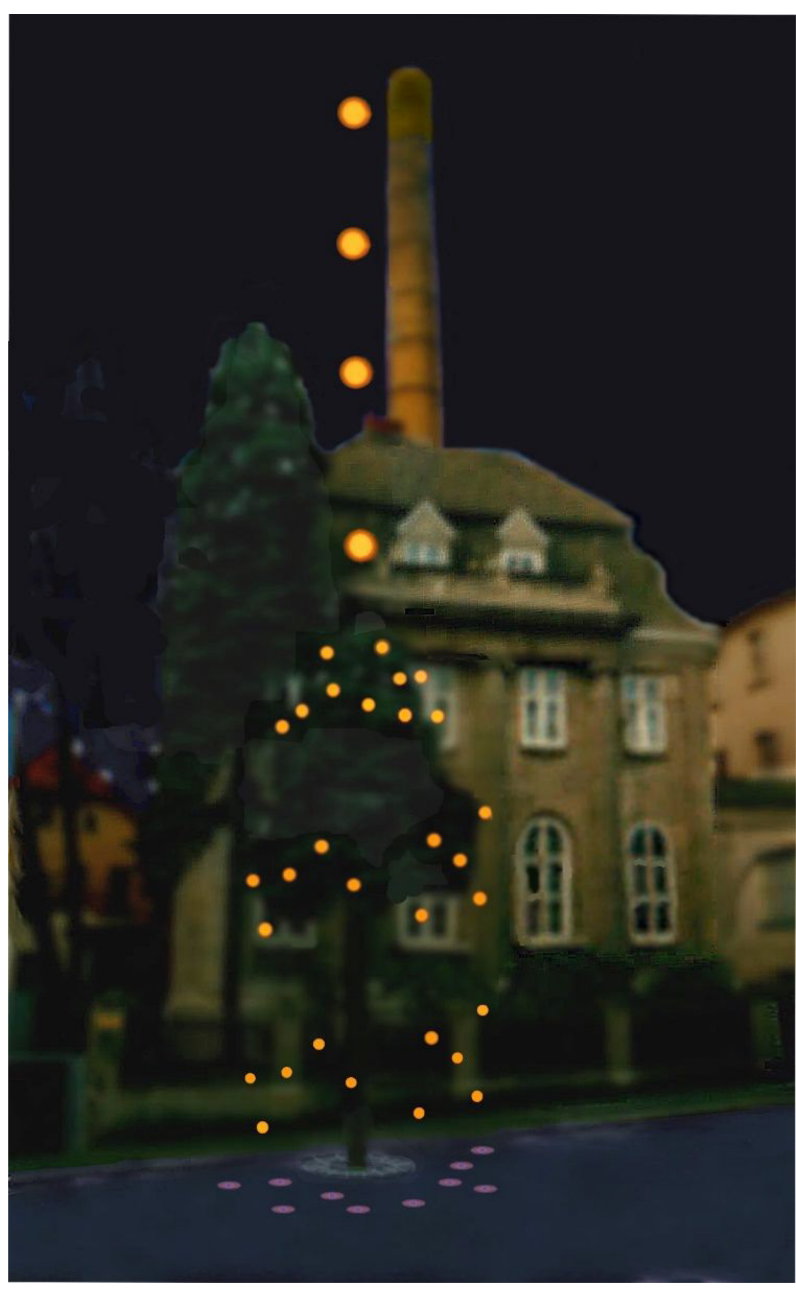

Figure 3. Synopsis of Wittmann's observation, 1951, by the witness - falling main object, fragmentation into smaller spheres, and their street impact. Computer simulation based on an original photograph of the site: Axel Wittmann.

\section{Other trained observers}

\subsection{Weather observers and coastguards}

Weather observers of meteorological stations are trained and predestined to see and report transient weather phenomena. From January 1874 to June 1888, the Harvard College Observatory was manned on Pikes Peak, Colorado, USA, for daily weather observations (Greely and Pickering, 1889). In their daily journal, a lightning strike at $500 \mathrm{ft}(152 \mathrm{~m})$ northeast was recorded on 16 June 1876, at 17:30 LT, which affected the observer who sat on a rock outside so that he felt aftereffects for another $15 \mathrm{~min}$. "An assistant, sawing wood in the shed at the time, received a similar shock, and says that a ball of lightning appeared to pass through the storeroom and woodshed in which he was working, leaving a strong sulfurous smell." The daily journal records another lightning strike on 12 August 1879, at 17:40 LT: "a bolt of lightning 
went through an arrester with the report of a rifle, throwing a ball of fire across the room against the stove and tin sheathing." At 18:35 LT a second strike damaged window, anemometer and telegraph wires. Both reports give no details of the objects. Pikes Peak with $4302 \mathrm{~m}$ is the highest summit in the southern Front Range of the Rocky Mountains.

On 15 April 1916, 18:20 LT, the summit and weather station of Puy de Dôme, a $1465 \mathrm{~m}$ high old volcano of Massif Central, Auvergne, France, were in fog, and weather observer Antoine Haynard was sitting at the telegraph when lightning damaged the set and gave him a shock. Looking out the south window, he saw at the same time ball lightning "with a little blurry outline that became oval and burst throwing 'tongues of fire' in all directions". At around 18:30 and 18:50, two more events occurred (Mathias, 1916) in the same shape and procedure as the first one. Physicist Emile Mathias, since 1910 director of the Puy de Dôme Observatory and professor at the Clermont-Ferrand science faculty, wrote an event report to the French Academy of Sciences. No other lightning was observed at that day. All objects appeared at the same point to the south, at first floor height of the observatory, had less than full moon size, were stationary, and lasted 2-3s before exploding. They were mauve white and "burst with the sound of a strong whip, projecting in all directions a light which lit the apartments". Objects two and three were seen from the kitchen by Antoine Heynard, his wife, and eldest son Francisque Heynard (Mathias, 1916).

Hermann Rubisoier, weather observer at the Mt Sonnblick summit observatory, $3106 \mathrm{~m}$, Salzburg Province, Austria, told the author, 1988, the following: in summer of 1947, he and a second observer were indoors before 15:00 LT, when during a near thunderstorm a yellow fiery ball of $1 \mathrm{~m}$ came from the telephone (which was broken afterwards), crossed the kitchen, got out of a window, and then rolled down the glacier in front of the house to end with a bang. The witnesses stood $1 \mathrm{~m}$ from its trajectory and heard a rushing sound. A second event happened in summer of 1949 in the afternoon, when the summit was in clouds and a thunderstorm in progress. Another yellow ball of $1 \mathrm{~m}$ destroyed an east side light pole outside the window of the "scholar's room" over ridge and glacier.

The crew of the Mt Fichtelberg meteorological mountain observatory, $1215 \mathrm{~m}$, in southern Saxony, Germany, have recorded many atmospheric phenomena (Hinz et al., 2017), including ball lightning on 10 May 1965, during a thunderstorm with gusts of up to wind force 12 and drifting snow. Helga Gaebler (2004), one of the day crew, remembers: "At breakfast time we saw through the window something bright coming our way along the house, kind of a ball, I would guess of football size." Speed was moderate but too quick to notice details. "It disappeared in the hatch of the attached shed.... Suddenly there was a splashing sound in the corner of our room, like from a big water-filled balloon thrown to the wall to burst." Apparently, the object had travelled through a hole in the shed (where electrical cables led to transmitters in the main office) to a socket in the corner. It caused no damage.

Anthony Dalton, a coastguard near Fishguard, Wales, UK, sent a report to the Meteorological Office in England: on 8 June 1977, sky cloudy, distant cumulonimbus, he saw at 02:27 LT a "very large (estimated bus sized) brilliant yellowgreen transparent ball with fuzzy outline" descend from the base of a towering cumulus (congestus) cloud and float down the hillside of Garn Fawr mountain. The ball was in sight for $7 \mathrm{~s}$ then "flickered out". Downward speed estimate was $2 \mathrm{~m} \mathrm{~s}^{-1}$. The internal structure appeared like fibres. Initially, brightness was like a neon advertising sign, which got more intense $3 \mathrm{~s}$ before disappearing. The object rotated horizontally and caused severe static on radio (Stenhoff, 1999, pp. 173-174).

It was 15 July 1985 when climate observer Kurt Krenn, station Wiel/Eibiswald, Styria, Austria, saw a severe thunderstorm cross the mountains with lightning after 21:30 LT. At 22:00, he noticed lightning with a blue-white flare that lasted for about $3 \mathrm{~min}$ and ended with two more lightning flashes and a local blackout. Other people had seen more a stationary blue-white ball at the Gontschnigg hill west of Eibiswald for $3 \mathrm{~min}$. In the evening of 4 July 1989, a thunderstorm front passed St Poelten, Lower Austria. Christian Witz, synoptic observer of the local weather station, was off duty, taking lightning photos near Senning, east of town. Around 21:00 LT it was dark because of heavy rain. After a ground stroke, Witz saw a white fuzzy ball above the ground about $300 \mathrm{~m}$ from the lightning location. It was stationary and went out after $7 \mathrm{~s}$. A time exposure with his camera showed a white blob (Keul, 1994). On 15 January 1994, thunderstorms moved in from the North Sea over Neuruppin, Brandenburg, Germany. Shortly after 17:00 LT, Thomas Hinz, the local weather observer on duty, saw a very bright lightning flash with thunder after $10 \mathrm{~s}$ to the north. In the following days, a series of observations from Neuruppin people were forthcoming. Fourteen witnesses described ball lightning, mostly outside their homes, size between 0.2 and $1 \mathrm{~m}$, seven objects were seen in motion. The German lightning location system BLIDS detected positive cloud-ground lightning of $370 \mathrm{kA}$ at 17:08:36 LT $6 \mathrm{~km}$ to the north (Baecker et al., 2007).

The tendency of weather services to do without observers and automate synoptic stations (including German mountaintop observatories) may be justified from an economic standpoint, but it eliminates high-quality observations of rare phenomena such as ball lightning. Whether this will be compensated by citizen science and the spread of mobile phone and web cameras remains uncertain.

\subsection{Amateur astronomers, military, and economic experts}

Philip M. Bagnall, network director of the British Meteor Society, awoke on 8 June 1974, at 01:36 LT at Wallsend, Tyne and Wear, UK, during a violent thunderstorm. He saw an or- 
ange sphere of $15 \mathrm{~cm}$ which was $60 \mathrm{~cm}$ near the window and $1.6 \mathrm{~m}$ off the floor near the foot of his bed. The object floated away from the window to $2.5 \mathrm{~m}$ where it stopped. It revolved about every $10 \mathrm{~s}$, had an intensity of $25-30 \mathrm{~W}$, and had no sound. Bagnall had the nerves to reach out and sense some heat $10 \mathrm{~cm}$ from it. He clapped his hands without effect on the object. Eventually, it moved up to the ceiling and "passed through it like a Hollywood ghost". Bagnall timed the duration of his observation with his watch at about $50 \mathrm{~s}$ (Stenhoff, 1999, pp. 174-175).

Wolfgang Vollmann, amateur astronomer working for the public observatory at Traiskirchen, looked out of the balcony door at his home in a high-rise, Pfaffstätten, Lower Austria, at the end of a thunderstorm shower on 28 March 1975. In a terrain incision between trees and industrial plants, near the Baden local train line, the witness saw shortly after 18:00 LT a stationary, bright yellow, full-moon-sized ball which disappeared in a flash of light after $1.5 \mathrm{~s}$. The rain had stopped, visibility was good, and no sound was heard (Keul, 1980).

Friedrich Wieser, Austrian Air Force colonel and member of the Tactical Air Command, drove in his car from Atzelsdorf to Blindenmarkt, Lower Austria, on 10 October 1977, around 19:00 LT. Moving parallel to federal highway B1 in darkness and a light rain shower, a reflection in a window front made him aware of an extremely bright object on B1, a bluish-white field of the size of a car. Wieser slowed down the car and lowered the window: "Suddenly it contracted like threads into a globe, jumped off at a high rate, turning yellow, orange, and red." The diffuse red body followed a slanted trajectory and touched down at the B1 2-5 km eastwards. "It went orange, yellow, and then dazzling again; was stationary for a short time; and then contracted to red, flying up at a oblique angle to disappear." The phenomenon lasted less than a minute and did not flicker or make a sound. Colonel Wieser had 10 years of military radar experience when he reported his observation to the author 1979 (Keul, 1980, 1981). In his interview, Friedrich Wieser told the author about his observation as a schoolboy in the summer of 1945/1946 at home with his mother in Neumarkt, Salzburg Province, Austria, at 16:00-17:00 LT. A luminous ball the size of an apple came in through the open top of a window, bounced elastic from windowsill and table down to the floor where it exploded loudly after less than $5 \mathrm{~s}$. There was also a lightning strike to the neighbour's chimney and to the Western Railway line.

After heavy thunderstorms over Vienna on 28 July 2020, Reinhard Wilhelm, executive director of a technical company and a graduated manager, and his wife went out into the garden of their home in Vienna's 22nd district (Neueßling) around 22:15 LT. Thunderstorms were still active. Looking east, they both saw something striking. Moving upwards, light seemed to concentrate and brighten into a white sphere which illuminated the clouds, circled shortly, stopped, then quickly flew up at an angle into the cloud layer and disappeared after $2 \mathrm{~s}$. Its light was white, steady. With $0.1^{\circ}$ size at $45^{\circ}$ elevation (i.e. $2 \mathrm{~km}$ oblique distance) just below the cloud base at $1500 \mathrm{~m}$, it was $3.5 \mathrm{~m}$ large. The 28 July was a hot day in Vienna with $37.2^{\circ} \mathrm{C}$, followed by a cold front with thunderstorms. At 22:00 LT, a synoptic station $4 \mathrm{~km}$ east reported $21^{\circ} \mathrm{C}, 80 \%$ relative humidity, wind of $15 \mathrm{~km} \mathrm{~h}^{-1}$ (gusts of $35 \mathrm{~km} \mathrm{~h}^{-1}$ ), $2.5 \mathrm{~mm}$ rain, and pressure of $1013 \mathrm{hPa}$. Visibility was $22 \mathrm{~km}$. ALDIS recorded 10 lightning events during 22:01-22:28 LT for $5 \mathrm{~km}$ around Neueßling. At 22:16:28 LT, a strong positive cloud-ground stroke with $+170.4 \mathrm{kA}$ happened $0.5 \mathrm{~km}$ west in the back of the witnesses. A study on 34 central European ball lightning events versus lightning location data showed 19 correlated positive and 15 negative strokes, with 28 cloud-ground strokes (Keul and Diendorfer, 2018). In contrast to this, in a 10-year interval, ALDIS recorded $17 \%$ positive lightning events at Austria (Schulz et al., 2005).

\section{Synopsis of cases}

Table 1 shows absolute values for seven main variables of the relatively small sample of 41 case abstracts reported by scientists and trained observers.

Most reports come from Europe (Austria, UK, Germany, Russia, France). One report each is from Spain and Latvia (not in Table 1). And there are five US cases from overseas.

Observation years range from 1868-2020, with a maxima during 1950-2000. Few reports predate 1900.

Observation months follow the seasonal thunderstorm maximum - 7 July, 5 June/August each.

Observation (local) time of day is also thunderstormrelated, rising after 12:00 and remaining high until midnight.

Reported object sizes (28 cases) range from $1.5 \mathrm{~cm}$ to $15 \mathrm{~m}$, with the maximum below $20 \mathrm{~cm}$ and several cases over $1 \mathrm{~m}$. Compared to 405 ball lightning cases from Austrian and German databases (Keul and Stummer, 2002), the scientists' size distribution is left skewed. The 2002 size results were the following: mean of $30.1-68.8 \mathrm{~cm}$, median of $25-30 \mathrm{~cm}$, mode of $30 \mathrm{~cm}$, and range of $1-1000 \mathrm{~cm}$.

Reported observation durations ( 25 cases) range from 1.5 to $180 \mathrm{~s}$ with the maximum under $3 \mathrm{~s}$ but $5-6$ cases in the higher categories. Mean is $19.5 \mathrm{~s}$, standard deviation is 38.6, median is 4.0 , and mode is $2.5 \mathrm{~s}$. The 405 ball lightning cases, 2002, had lower means (7.7-15.4 s), median of 3-5, mode of 2-5, and range of 1-900 s.

Reported association with thunderstorms were the following: $73 \%$ occurred within thunderstorms, $10 \%$ before or after, and $17 \%$ without a connection. Seventeen witnesses (41\%) reported a simultaneous lightning stroke. The 405 ball lightning samples were the following: simultaneously $64 \%-$ $72 \%$, before or after $11 \%-25 \%$, and no connection $6 \%-$ $14 \%$.

Looking at some phenomenological categories, 24 happened outdoors, 8 indoors, and 9 both in- and outdoors. Six objects were dazzlingly bright, two translucent, four had a corona, three rotated, and two bounced. Motion (33 reports) 
Table 1. Absolute values for reported country, year, month, local time of observation, object size, observation duration, and thunderstorm link of report.

\begin{tabular}{|c|c|c|c|c|c|c|}
\hline Country & $\begin{array}{l}\text { Austria } \\
14\end{array}$ & $\begin{array}{l}\text { UK } \\
6\end{array}$ & $\begin{array}{l}\text { Germany } \\
6\end{array}$ & $\begin{array}{l}\text { USA } \\
5\end{array}$ & Russia 5 & France 3 \\
\hline Year & $\begin{array}{l}<1900 \\
5\end{array}$ & $\begin{array}{l}1900<50 \\
11\end{array}$ & $\begin{array}{l}1950<2000 \\
23\end{array}$ & $\begin{array}{l}>2000 \\
2\end{array}$ & & \\
\hline Month & $\begin{array}{l}\text { Jan-Mar } \\
5\end{array}$ & $\begin{array}{l}\text { Apr-Jun } \\
9\end{array}$ & $\begin{array}{l}\text { Jul-Sep } \\
12\end{array}$ & $\begin{array}{l}\text { Oct-Dec } \\
4\end{array}$ & & \\
\hline Local time & $\begin{array}{l}0<6 \\
4\end{array}$ & $\begin{array}{l}6<12 \\
2\end{array}$ & $\begin{array}{l}12<18 \\
12\end{array}$ & $\begin{array}{l}18<24 \\
12\end{array}$ & & \\
\hline Size & $\begin{array}{l}1.5<20 \mathrm{~cm} \\
19\end{array}$ & $\begin{array}{l}20<50 \mathrm{~cm} \\
0\end{array}$ & $\begin{array}{l}50 \mathrm{~cm}<1 \mathrm{~m} \\
1\end{array}$ & $\begin{array}{l}>1 \mathrm{~m} \\
8\end{array}$ & & \\
\hline Duration & $\begin{array}{l}<3 \mathrm{~s} \\
8\end{array}$ & $\begin{array}{l}3<5 \mathrm{~s} \\
6\end{array}$ & $\begin{array}{l}5<10 \mathrm{~s} \\
5\end{array}$ & $\begin{array}{l}>10 \mathrm{~s} \\
6\end{array}$ & & \\
\hline Thunderstorm & $\begin{array}{l}\text { around } \\
4\end{array}$ & $\begin{array}{l}\text { in } \\
30\end{array}$ & $\begin{array}{l}\text { none } \\
7\end{array}$ & & & \\
\hline
\end{tabular}

was horizontal (11) or complex (9); seven were stationary and six downwards. Three produced sound simultaneously, two sparks, two smoke, four odour (ozone or sulfur), eight caused (minor) damage, and nine exploded loudly. Two cases with temporary (arm) paralysis belong to the subgroup medical effects (see also Paris 1889 in the following section).

Reported object relations were the following: nine mountains; six telephone, power lines, or power station; four aeroplanes; three lakes or rivers; one tower; and one sailboat. One object penetrated a wall, one disappeared into a wall, one split, and two phenomena were repeaters.

Thus, even this relatively small sample of educated and trained observers shows a variety of situations, object sizes, and case durations, and some outliers are hard to integrate into one general ball lightning model. This has led some researchers (as Rakov and Uman, 2003) to assume several types of ball lightning. Epistemologically, it would be odd to define a "ball lightning norm" and a priori exclude cases that do not meet this definition. Regardless of all problems with an explanatory theory, detailed case reports should be documented. Scientists who read the article and who have not reported their experience are invited to share it with the author.

\section{Other influential or notable cases}

A citation classic in ball lightning literature (Singer, 1971; Barry, 1980) as well as in popular articles is the case of Georg Wilhelm Richmann, a Baltic German physicist and member of the St Petersburg Academy of Sciences, who, during work on atmospheric electricity, was electrocuted in 1753. From an investigation protocol with autopsy results (Anonymous, 1755 , pp. 64-68), it is obvious that it was a conven- tional lightning accident caused by a non-grounded conductor. However, a popular engraving pictured a lightning ball that hit Richmann. As in the 1818 Frankenstein novel, the grim fate of an avantgarde scientist sounded plausible. Ball lightning acquired a deadly and destructive popular image fed by injuries and damage caused by ordinary cloud-ground strokes.

Jean-Martin Charcot, physician and founder of modern neurology, Professor at the University of Paris and associated with Salpêtrière Hospital, was also a teacher of Sigmund Freud in 1885. Freud translated Charcot's lectures (1889) into German 1892, as did Max Kahane 1895. The latter (1895, pp. 373-399) contain the demonstration of 28 May 1889 of D-cy (anonymized in original source), 45 years, a former marine soldier already suffering from depression and exhaustion from overwork. He walked on 7 May 1889 from Noisy le Sec northeast of Paris towards the city. Between 15:00 and 16:00 LT, thunder and heavy rain started. D-cy reports the following: "Then, lightning and thunder came together, like a cannon shot with ... shattering plates. ... I saw on the road in 2-3 $\mathrm{m}$ a luminous whirling fireball ... shape of a small beer barrel, about $50 \mathrm{~cm}$ long.... I saw three grey clouds coming from the fireball with a suffocating, irritant odour like sulfur or fizzed gunpowder (see a situation sketch in Fig. 4). At the same moment, my left leg was hit hard, I fell to the ground and passed out." When D-cy woke up again, he noticed urinary loss, stood up with effort, trembled, and cried. Limping on to Paris, he acted disturbed, aggressive, then babbling childishly; $16 \mathrm{~d}$ after his accident, he was sent to Charcot's clinic. Comparing D-cy's testimony with Sestier and Galli, Charcot concluded "One cannot doubt that our patient really saw ball lightning." He distinguished the short-lived neurological effects (keraunoparalysis) from a 


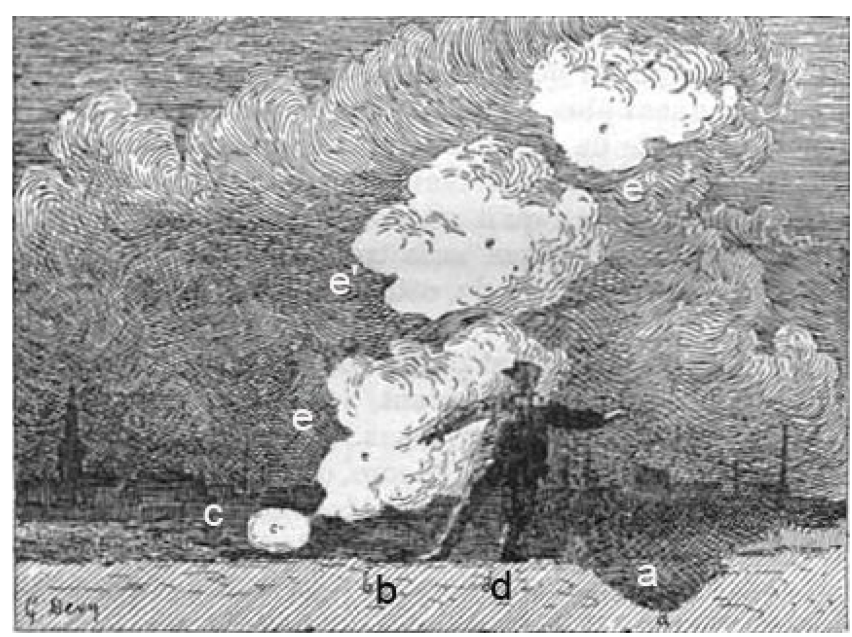

Figure 4. Figure 95 from Charcot (1895, p. 377) with German legend: "After a sketch of patient: a - the trench, b - the road, $\mathrm{c}-$ the luminous barrel, $\mathrm{d}$ - our sick one, e, $\mathrm{e}^{\prime}, \mathrm{e}^{\prime \prime}-$ the clouds of smoke". Source: Engraving Fig. 95, Charcot (1889, p. 439). In Digitale Sammlungen, Creative Commons, https://bildsuche. digitale-sammlungen.de/index.html?c=viewer\&bandnummer= bsb00081185\&pimage $=00443 \& l v=1 \& v=100 \& 1=$ de\#, last access: 23 January 2021. Reproduction and enlarged inserts: author.

long-lived traumatic neurosis (skin anaesthesia, motor paralysis, sensory losses, thunderstorm phobia, etc.). The patient left the clinic on 11 July in a better physical condition but still with neurotic complaints. Charcot's discrimination between keraunoparalysis and neuropsychological aftereffects is still made in medicine (Andrews et al., 2017).

One of the most-cited ball lightning events happened at Dorstone, Herefordshire, UK, and was reported to a newspaper by W. Morris (1936): "During a thunderstorm I saw a large, red hot ball come down from the sky. It struck our house, cut the telephone wires, burnt the window frame, and then buried itself in a tub of water, which was underneath. The water boiled for some minutes afterwards, but when it was cool enough for me to search I could find nothing in it." This is the whole available case documentation, but the chance to compute the ball's energy density electrified researchers (Singer, 1971; Stenhoff, 1999). With different ball diameters, an assumed amount of four gallons $(18 \mathrm{~L})$ of water, and a temperature rise from $10-20$ to $60^{\circ} \mathrm{C}$, the calculations found that at least $2 \times 10^{3} \mathrm{~J} \mathrm{~cm}^{-3}$ would be involved (Barry, 1980).

On 23 June 2008, at about 20:45 LT, Rozlyn Krjcik, administrative director emeritus of the New York State Spinal Cord Injury Center, Poughquag, New York, USA, arrived at her Poughquag home by car in heavy rain and with lightning around. Waiting in her car for the rain to decrease, she had the front glass porch in view (Stephan et al., 2016, p. 33): "I was stunned. ... I saw that fiery ball, yellow-flame appearance in my front door. ... It was the centre of the door, at least twice, two and a half times more area than you'd expect from that small cantaloupe-size blue object I saw." The glowing blue sphere was $14 \mathrm{~cm}$ in diameter and then flew away between her house and her car. Glass types fluoresce when subjected to ionizing radiation of $<375 \mathrm{~nm}$ (UV light or X-rays) because of heavy metals in the glass. Calibrated quantitative fluorometry measurements of the NY porch window in June 2016 found that for a floodlight illumination, the object's ionizing-radiation output was $10 \mathrm{~W}$; if considerably brighter, it was $100 \mathrm{~W}$.

An innovative field experiment was carried out by Martin A. Uman's US research group (Hill et al., 2010): at the military base Camp Blanding, Florida, the group had already triggered numerous lightning strikes by rockets with a trailed metal wire. In 2008, triggered lightning was conducted to over 100 substances on the ground, including salt water, silicon wafers, stainless steel, or conifer branches. The resulting phenomena were photographed and analysed. So, a flame was created for over half a second over salt water, glowing silicon fragments fell down for $1 \mathrm{~s}$, a flashover on the steel surface formed a $33 \mathrm{~cm}$ ball of light, and the discharge into the conifer branches was visible for half a second. Uman and colleagues call what was produced not ball lightning but point to interesting effects of different materials under the influence of lightning.

An international high-impact article by physicist Jianyong Cen and colleagues from Lanzhou College (2014) reported an incident during a field project at Xining on the $2500 \mathrm{~m}$ high Qinghai Plateau, China. Two video cameras with slitless spectroscopy (diffraction grating) were used to monitor lightning. During a thunderstorm of 23 July 2012, the cameras recorded a $1.64 \mathrm{~s}$ ball lightning episode at 21:55 LT. The object formed out of a cloud-ground lightning channel and spectra of both were obtained. The ball lightning spectrum showed lines due to $\mathrm{Fe}, \mathrm{CA}, \mathrm{Si}, \mathrm{N}$, and $\mathrm{O}$ consistent with the Abrahamson and Dinniss (2002) soil strike theory. The cameras pointed to a $200 \mathrm{~m}$ high northeast hill crossed by a high-tension power line. The author's email contact with Cen in February 2014 helped to specify the event - the ball lightning object formed on the ground near a tower of the power line, and a burnt patch was later found on the slope. Cloudground lightning struck the ground not the power line.

Anatoly Il'ich Nikitin and colleagues, Russia, field investigated a video-documented ball lightning incident at Mitino, a northwest district of Moscow, Russia, on 27 July 2015 (Nikitin et al., 2018), after 18:30 LT. Three independent observers in the Mitino district (Egor Chichin, Vladimir Sokolov, and Dmitry Novosyolov) noticed a glowing object moving erratically above apartment buildings and forest, near a high-tension power line, for about $5 \mathrm{~min}$. For different periods of time $(141,125$, and $76 \mathrm{~s})$, each of the three observers videorecorded the object by mobile phone. Triangulation of the simultaneous records helped to ascertain position and height above ground, which was between 30 and $140 \mathrm{~m}$. Most of the time, the object velocity was $6 \mathrm{~m} \mathrm{~s}^{-1}$ or 
less, over a ground space of $12 \times 100 \mathrm{~m}$; then it increased to $15 \mathrm{~m} \mathrm{~s}^{-1}$ and it disappeared up into a cloud. The object size was about $75 \mathrm{~cm}$ (Nikitin et al., 2018). The publication gives a wind speed of $100 \mathrm{~km} \mathrm{~h}^{-1}$. The author found Scheremetjevo airport data just north of Mitino: at 18:30 LT wind was $18 \mathrm{~km} \mathrm{~h}^{-1}$ east, cloudy. A rain shower with wind of $47 \mathrm{~km} \mathrm{~h}^{-1}$ at 19:00, thunderstorms 19:30-21:00 LT.

\section{Conclusions}

Looking back onto 41 ball lightning observations by scientists and trained professionals published or from researchers' records and six other cases with high investigation effort, it can be discussed how such reports and material-evidence cases may promote fieldwork and stimulate and evaluate ball lightning theories to overcome Turner's "fragmented science" (2001).

The main difference between modern science and Frankenstein's laboratory is guiding research paradigms that - in the case of natural phenomena - condition a proper order of systematic data acquisition, formation, and testing of hypotheses and theories, and - if possible - laboratory simulation. In the case of ball lightning, the research logic is distorted by a random phenomenon that is hard to observe, irreproducible, and mostly reported by change. Weird popular press stories and a lack of economic (except some military) interest did not encourage scientific community nor weather services to deal with this "unsolved problem in atmospheric physics" (Stenhoff, 1999). Most ball lightning research was (and still is) part-time and individualized - some people collecting data, some theorizing, some doing laboratory tests. Big databases (e.g. Brand, Stakhanov, Rayle, McNally) ended and amateurs took over, theorists opened at least 16 explanatory domains (Rakov and Uman, 2003, p. 664), and a diversity of laboratory simulations developed laterally.

Nevertheless, the author is still optimistic that scientific progress will be faster when capacities are better coordinated. A new US research group is just underway organizing online report collection and investigation (Sonnenfeld et al., 2020). With physical evidence cases like the Dorstone tub, the Poughquag glass, or the Qinghai spectrum as benchmarks and digital material from abundantly present mobile phones and webcams, systematic multidisciplinary case documentation and discussion can lead to a database against which ball lightning theories and simulations can be critically assessed.

Data availability. Of the 41 case reports by scientists and trained observers, 20 were published and are accessible via the internet. Fifteen case reports are from the author's database, and six are from the Russian database of Vladimir Bychkov. The six influential or notable cases were published and are accessible via the internet.
Competing interests. The author declares that there is no conflict of interest.

Acknowledgements. Pioneer ball lightning case work in central Europe was done by Anton Puehringer, Austria, and by Axel Wittmann and Karl-Heinz Hentschel, Germany. Investigations of the author, 1974-2020, were voluntary work; support came from Oliver Stummer. The author wishes to thank all central European observers and numerous local and national newspapers and electronic media for carrying calls for reports. Axel Wittmann contributed four case reports and two images, and Vladimir Bychkov contributed six case reports for this compilation.

Review statement. This paper was edited by Hans Volkert and reviewed by two anonymous referees.

\section{References}

Abrahamson, J. and Diniss, J.: Ball lightning caused by oxidation of nanoparticle networks from normal lightning strikes on soil, Nature, 403, 519-521, https://www.nature.com/articles/35000525, 2002.

Andrews, C. J., Reisner, A. D., and Cooper, M. A.: Post electrical or lightning injury syndrome: a proposal for an American Psychiatric Association's Diagnostic and Statistical Manual formulation with implications for treatment, Neural Regen. Res., 12, 1405-1412, https://www.ncbi.nlm.nih.gov/pmc/ articles/PMC5649452/, 2017.

Anonymous: An account of the death of Mr. George William Richmann, professor of experimental philosophy, a member of the Imperial Academy of Sciences at Petersburg, Philos. T. R. Soc., 49, 61-69, 1755.

Anonymous: Ball lightning, Meteorol. Mag., 25, p. 99, 1890.

Anonymous: James Durward, C. M. G., M. A., Meteorol. Mag., 85, 97-98, 1956.

Arago, F.: Sur le tonnerre, Annuaire pour l'an 1838, présenté au roi, par le bureau des longitudes, Notices scientifiques, Bachelier, Paris, France, 1837 (in French).

Baecker, D., Boerner, H., Naether, K., and Naether, S.: Multiple ball lightning observations at Neuruppin, Germany, J. Meteorol., 32, 193-200, http://www.ijmet.org/wp-content/uploads/ 2015/04/320.pdf, 2007.

Barry, J. D.: Ball lightning and bead lightning, Plenum, New York, USA, 1980.

Boerner, H.: Ball lightning, A popular guide to a longstanding mystery in atmospheric electricity, Springer, Cham, UK, 2019.

Brand, W.: Der Kugelblitz, Henri Grand, Hamburg, Germany, 1923 (in German).

Brand, W.: Der Kugelblitz (reprint), Kessel, Remagen-Oberwinter, Germany, 2010 (in German).

Bychkov, V. L., Nikitin, A. I., and Dijkhuis, G. C.: Ball lightning investigations, in: The atmosphere and ionosphere, Physics of earth and space environments, edited by: Bychkov, V. L., Nikitin, A. I., and Dijkhuis, G. C., Springer, Dordrecht, the Netherlands, 201-373, https://doi.org/10.1007/97890-481-3212-6_6, 2010. 
Bychkov, V. L.: Russian ball lightning files (English translation), personal communication, July 292020.

Cen, J., Yuan, P., and Xue, S.: Observation of the optical and spectral characteristics of ball lightning, Phys. Rev. Lett., 112, 035001, https://doi.org/10.1103/PhysRevLett.112.035001, 2014.

Charcot, J. M.: Leçons du Mardi à la salpêtrière: policliniques, 1888-1889, notes de cours de M. M. Blin, Charcot (fils) et Colin, Bureaux du Progrès Médical, Paris, France, 1889 (in French).

Charcot, J. M.: Poliklinische Vorträge, II. Band, Schuljahr 18881889, Deuticke, Leipzig, Germany, 1895 (in German, translation from the French by Kahane, M.).

Davies, P.: Great balls of fire, New Scientist, 24, 64-67, 1987.

Dmitriev, M. T.: Priroda sharovoi molnii, Priroda, 6, 98-106, 1967 (in Russian).

Dolezalek, H.: Einige Kugelblitz-Beobachtungen, Geofis. Pura Appl., 20, 183-185, 1951 (in German).

Domínguez-Castro, F.: An early record of ball lightning: Oliva (Spain), 1619, Hist. Geo Space. Sci., 9, 79-83, https://doi.org/10.5194/hgss-9-79-2018, 2018.

Furnham, A.: Lay theories: everyday understanding of problems in the social sciences, Oxford, Pergamon Press, UK, 1988.

Gaebler, H.: Geschichten, Osiris, Leipzig, Germany, 2004 (in German).

Gerlach, W.: Ueber die Beobachtung eines Kugelblitzes, Naturwissenschaften, 15, 522-523, 1927 (in German).

Gold, E.: Thunderbolts: The electric phenomena of thunderstorms, Nature, 169, 561-563, https://www.nature.com/articles/ 169561a0, 1952.

Greely, A. W. and Pickering, E. C.: Meteorological observations made on the summit of Pike's Peak, Colorado January, 1874, to June 1888, Annals of the Astronomical observatory of Harvard College, 22, 475 pp., http://articles.adsabs.harvard.edu/pdf/ 1889AnHar..22...1P, 1889.

Haidinger, M. W. V.: Elektrische Meteore am 20. October 1868 in Wien beobachtet, Sitzungsberichte der Mathematisch-Naturwissenschaftlichen Klasse der Kaiserlichen Akademie der Wissenschaften, 58, 761-769, https://doi.org/10.1016/j.jastp.2010.04.009, 1868 (in German).

Hill, J. D., Uman, M. A., Stapleton, M., Jordan, D. M., Chebaro, A. M., and Biagi, C. J.: Attempts to create ball lightning with triggered lightning, J. Atm. Sol. Terr. Phy., 72, 913-925, https://doi.org/10.1016/j.jastp.2010.04.009, 2010.

Hinz, C., Hinz, W., Franze, G., Barth, M., and Bach, S.: Optische Erscheinungen und andere ungewöhnliche Wetterphänomene auf der Wetterwarte Fichtelberg, Deutscher Wetterdienst, Offenbach, Germany, 2017 (in German).

Humphreys, W.: Ball lightning, P. Am. Philos. Soc., 76, 613-626, 1936.

Jennison, R. C.: Ball lightning, Nature, 224, 895, https://www. nature.com/articles/224895a0, 1969.

Keul, A. G.: Kugelblitze, Wetter und Leben, 32, 167-180, https://data.ccca.ac.at/dataset/wetter-und-leben-jahrgang-32_ heft-3-v01, 1980 (in German).

Keul, A. G.: Ball lightning reports, Naturwissenschaften, 68, 134136, available at: http://www.digizeitschriften.de/dms/img/ ?PID=PPN34557155X_0068\%7CLOG_0032 (last access: 23 February 2021), 1981.
Keul, A. G.: Possible ball lightning colour photograph from Sankt Gallenkirch, Vorarlberg, Austria, J. Meteorol., 17, 73-82, http: //www.ijmet.org/wp-content/uploads/2016/05/167.pdf, 1992.

Keul, A. G.: Progress in ball lightning research, in: Proceedings of the interdisciplinary congress Vizotum, Salzburg, Austria, 20-22 September 1993, 126 pp., 1993.

Keul, A. G.: Ball lightning colour photograph from Senning, Lower Austria, J. Meteorol., 19, 10-15, http://www.ijmet.org/ wp-content/uploads/2016/05/185.pdf, 1994.

Keul, A. G.: A possible ball lightning webcam record from Zwoenitz, Germany, J. Meteorol., 29, 168-173, http://www. ijmet.org/wp-content/uploads/2015/04/289.pdf, 2004.

Keul, A. G. and Diendorfer, G.: Assessment of ball lightning cases by correlated LLS data, 34th International Conference on Lightning Protection, Rzeszow, Poland, 2-7 September 2018, https://doi.org/10.1109/ICLP.2018.8503422, 2018.

Keul, A.G. and Stummer, O.: Comparative analysis of 405 Central European ball lightning cases, J. Meteorol., 27, 385-393, http: //www.ijmet.org/wp-content/uploads/2016/09/274.pdf, 2002.

Kugelblitz: (Author's ball lightning webpage, German and English): http://kugelblitz.uni-salzburg.ac.at/, last acess: 23 February 2021.

Marsh, O. C.: Globular lightning, Nature, 53, p. 152, 1895.

Mathias, M. E.: Sur trois observations d' eclairs en boule faites au somnet du Puy de Dome, Comptes Rendus de l'Academie des Sciences, 25, p. 642, 1916 (in French).

McNally, J. R.: Preliminary report on ball lightning, Oak Ridge National Laboratory No. 3938, available at: https://www.osti.gov/ servlets/purl/4533050 (last access: 23 February 2021), 1966.

Morris, W.: A thunderstorm mystery, London Daily Mail, 1936.

Nikitin, A. I., Bychkov, V. L., Nikitina, T. F. and Stepanov, I. G.: Analysis of the unique case of ball lightning observation in Mitino, the northwest district of Moscow, J. Atm. Sol. Terr. Phy., 179, 97-104, https://doi.org/10.1016/j.jastp.2018.07.001, 2018.

Rakov, V. A. and Uman, M. A.: Lightning, Physics and effects, Cambridge University Press, Cambridge, UK, 2003.

Rayle, W. D.: Ball lightning characteristics, Technical Note NASA TN D-3188, National Aeronautics and Space Administration, Washington, DC, USA, available at: https://ntrs.nasa.gov/ citations/19660006027 (last access: 23 February 2021), 1966.

Schreuder, D. A.: Road lighting for safety, Thomas Telford, London, UK, 1998.

Schulz, W., Cummins, K., Diendorfer, G., and Dorninger, M.: Cloud-to-ground lightning in Austria: A 10-year study using data from a lightning location system, J. Geophys. Res., 110, D09101, https://doi.org/10.1029/2004JD005332, 2005.

Shmatov, M. L. and Stephan, K. D.: Advances in ball lightning research, J. Atm. Sol. Terr. Phy., 195, 105-115, https://doi.org/10.1016/j.jastp.2019.105115, 2019.

Singer, S.: The nature of ball lightning, Plenum, New York, USA, 1971.

Smirnov, B. M.: Physics of ball lightning, Phys. Rep., 224, 151236, https://doi.org/10.1016/0370-1573(93)90121-S, 1993.

Sonnenfeld, R., Stephan, K., Keul, A. G., Edelman, I., and Jimenez, S.: Applying modern meteorological tools to the study of ball lightning, AGU Fall Meeting, 1-17 December 2020, https://doi.org/10.1002/essoar.10505247.1, 2020.

Stakhanov, I. P.: The physical nature of ball lightning, Atomizdat, Moscow, Russia, 1979 (in Russian). 
Stenhoff, M.: Ball lightning, An unsolved problem in atmospheric physics, Kluwer, New York, USA, 1999.

Stephan, K. D., Krajcik, R., and Martin, R. M.: Fluorescence caused by ionizing radiation from ball lightning: Observation and quantitative analysis, J. Atm. Sol. Terr. Phy., 148, 32-38, https://doi.org/10.1016/j.jastp.2016.08.005, 2016.

Tar, D.: Observation of lightning ball (ball lightning), in: Proceedings of the 9th International Symposium on ball lightning (ISBL-06), Eindhoven, The Netherlands, 16-19 August 2006, 222-232, available at: https://arxiv.org/ftp/arxiv/papers/ 0910/0910.0783.pdf (last access: 23 February 2021), 2006.

Thottappillil, R.: The physics of lightning flash and its effects, COST P18 proposal, Memorandum of Understanding, Technical Annex, Uppsala, Sweden, available at: https://www. cost.eu/actions/P18/ (last access: 23 January 2021), 2005.

Tompkins, D. R., Rodney, P. F., and Gooding, R.: Possible photographic observations of ball lightning, B. Am. Phys. Soc., 20, 659-663, 1975.

Tuck, J. L.: Ball lightning, A status summary to November 1971, Los Alamos, NTIS, Springfield, Virginia, USA, available at: https://digital.library.unt.edu/ark:/67531/metadc1030714/m2/ 1/high_res_d/4692288.pdf (last access: 23 February 2021), 1971.
Turner, D. J.: The fragmented science of ball lightning (with comment), Philos. T. R. Soc. A, 360, 107-152, https://royalsocietypublishing.org/doi/10.1098/rsta.2001.0921, 2001.

Vaquero, J. M.: Ball lightning: a Renaissance account from Zafra (Spain), Hist. Geo Space. Sci., 8, 53-56, https://doi.org/10.5194/hgss-8-53-2017, 2017.

Wittmann, A.: In support of a physical explanation of ball lightning, Nature, 232, p. 625, https://www.nature.com/articles/232625a0, 1971.

Wittmann, A. D.: More on the Neustadt multiple ball lightning case, in: Progress in ball lightning research, Proceedings of the interdisciplinary congress Vizotum, Salzburg, Austria, Sep 20-22, 1993, edited by: Keul, A. G., Vizotum, Salzburg, Austria, 110 114, 1993.

Zedelius, C. M., Müller, B., and Schooler, J.: The science of lay theories, Springer, Cham, UK, 2017. 